\title{
Pseudoinfectious mononucleosis: a presentation of Bartonella henselae infection
}

\author{
F Massei, F Messina, M Massimetti, P Macchia, G Maggiore
}

\begin{abstract}
Six children presented during one year with clinical features of infectious mononucleosis, but with laboratory findings of leucocytosis with neutrophilia, increased erythrocyte sedimentation rate, and hypergammaglobulinaemia. Serology for Epstein-Barr virus, cytomegalovirus, adenovirus, and Toxoplasma gondii was negative, while anti-Bartonella henselae IgM with high IgG titre ( $\geqslant 1$ I 1024) was present in all. All children had contact with kittens. No specific treatment was administered and all recovered.
\end{abstract}

(Arch Dis Child 2000;83:443-444)

Keywords: Bartonella henselae; infectious mononucleosis; cat scratch disease

Dipartimento di

Medicina della

Procreazione e

dell'Età Evolutiva,

Università di Pisa, Via

Roma 67, 56100 Pisa,

Italy

F Massei

M Massimetti

P Macchia

G Maggiore

Divisione di Malattie Infettive Ospedale di Cisanello, Pisa, Italy

F Messina

Correspondence to:

Prof. Maggiore

g.maggiore@clp.med.unipi.it

Accepted 20 July 2000
Infectious mononucleosis like illness is a multiaetiological clinical syndrome characterised by notable cervical and/or submandibular lymphadenopathy, pharyngotonsillitis, and commonly fever and splenomegaly. Cytomegalovirus (CMV) is the most frequent aetiological agent; less frequently Toxoplasma gondii, adenovirus, rubella, HIV, and herpes viruses may be involved. ${ }^{1}$ Single cases of rare aetiology caused by drugs or unusual viruses have also been reported, but a number of cases remain undiagnosed.

We observed, over one year, six children with clinical features mimicking infectious mononucleosis in whom we were able to show Bartonella henselae infection by appropriate serology.

\section{Methods}

During one year, all children presenting at the paediatric department of the University of Pisa with clinical features suggesting infectious mononucleosis were investigated for EpsteinBarr virus (EBV), CMV, T gondii, and adenovirus by commercially available serological assays. Serum samples were also tested for the presence of $\operatorname{IgG}$ and $\operatorname{IgM}$ class antibodies against $B$ henselae by indirect immunofluorescence antibody test (BIOS $\mathrm{GmbH}$, München, Germany) as previously described. ${ }^{2}$ An indirect antibody titre of $1 / 256$ or above in the presence of specific $\operatorname{IgM}$ was considered indicative of $B$ henselae infection.

\section{Results}

Table 1 details the principal clinical manifestations and laboratory findings of the six patients. All were outpatients and were in good general condition despite high $\left(>39^{\circ} \mathrm{C}\right)$ and prolonged (range 5-35 days) fever. All had bilateral cervical and/or submandibular adenomegaly. The lymph nodes were painless, not inflamed, and exhibited a firm consistency. Other clinical features included slightly erythematous pharyngitis, with tonsillitis without membrane formation and with exudate in three patients; periorbital oedema; nasal obstruction; and splenomegaly in five patients.

Laboratory findings showed: leucocytosis $\left(15.5-28.5 \times 10^{9} / 1\right)$ with neutrophilia, thrombocytosis $\left(\geqslant 400 \times 10^{9} / 1\right)$, and increased erythrocyte sedimentation rate (ESR; range 54-129 $\mathrm{mm} / \mathrm{h}$ ) in all patients. C reactive protein was increased to up to 12 times the upper limit of normal in all but one. All had hypergammaglobulinaemia; in particular, IgM levels of up to $0.78 \mathrm{~g} / 1$ were present, and IgG levels were

Table 1 Clinical and laboratory features in six children with B henselae infectious mononucleosis like illness

\begin{tabular}{|c|c|c|c|c|c|c|}
\hline & Patient 1 & Patient 2 & Patient 3 & Patient 4 & Patient 5 & Patient 6 \\
\hline Age (y) & 3.5 & 2.1 & 2.7 & 2.3 & 5 & 4 \\
\hline Fever $>39^{\circ} \mathrm{C}$ (days) & 35 & 9 & 15 & 10 & 10 & 5 \\
\hline Periorbital oedema & $\mathrm{P}$ & $\mathrm{P}$ & $\mathrm{P}$ & A & $\mathrm{P}$ & $\mathrm{P}$ \\
\hline Adenomegaly & $\begin{array}{l}\text { Cervical } \\
\text { submandibular }\end{array}$ & $\begin{array}{l}\text { Cervical } \\
\text { submandibular }\end{array}$ & $\begin{array}{l}\text { Cervical } \\
\text { submandibular }\end{array}$ & Cervical & $\begin{array}{l}\text { Cervical } \\
\text { subandibular }\end{array}$ & $\begin{array}{l}\text { Cervical } \\
\text { submandibular }\end{array}$ \\
\hline Tonsillitis with exudate & $\mathrm{P}$ & A & $\mathrm{P}$ & $\mathrm{P}$ & A & A \\
\hline Nasal obstruction & A & $\mathrm{P}$ & $\mathrm{P}$ & $\mathrm{P}$ & $\mathrm{P}$ & $\mathrm{P}$ \\
\hline Splenomegaly & $\mathrm{P}$ & $\mathrm{P}$ & $\mathrm{P}$ & A & $\mathrm{P}$ & $\mathrm{P}$ \\
\hline $\operatorname{ESR}(\mathrm{mm} / \mathrm{h})$ & 82 & 129 & 100 & 68 & 81 & 54 \\
\hline Leucocytes $\left(\times 10^{9} / 1\right)$ & 18 & 11.6 & 28.5 & 20.4 & 15.4 & 15.5 \\
\hline Neutrophils $\left(\times 10^{9} / 1\right)$ & 0.75 & 0.68 & 0.73 & 0.56 & 0.79 & 0.59 \\
\hline Platelets $\left(\times 10^{9} / 1\right)$ & 500 & 470 & 530 & 465 & 444 & 400 \\
\hline $\mathrm{CRP} \times \mathrm{N}^{\star}$ & $\mathrm{N}$ & 2 & 12 & 3 & 6 & 3 \\
\hline $\operatorname{IgG}(\mathrm{g} / \mathrm{l})$ & 2.30 & 3.82 & 0.96 & 1.43 & 1.78 & 1.46 \\
\hline $\operatorname{Ig} \mathrm{A}(\mathrm{g} / \mathrm{l})$ & 0.17 & 0.14 & 0.16 & 0.20 & 0.21 & 0.12 \\
\hline $\operatorname{Ig} M(g / 1)$ & 0.78 & 0.27 & 0.27 & 0.42 & 0.49 & 0.45 \\
\hline Alanine aminotransferase activity & $\mathrm{N}$ & $\mathrm{N}$ & $\mathrm{N}$ & $\mathrm{N}$ & $\mathrm{N}$ & $\mathrm{N}$ \\
\hline$B$ henselae IFA-IgM & POS & POS & POS & POS & POS & POS \\
\hline$B$ henselae IFA-IgG & $1 / 1024$ & $>1 / 1024$ & $>1 / 1024$ & $1 / 2048$ & $1 / 1024$ & $1 / 1024$ \\
\hline Recovery (days) & 60 & 10 & 15 & 20 & 15 & 15 \\
\hline
\end{tabular}

${ }^{\star} \mathrm{N},<0.05 \mathrm{~g} / \mathrm{l}$

$\mathrm{P}$, present; A, absent; N, normal activity; POS, positive; IFA, immunofluorescence antibody. 
increased, sometimes notably (3.82 g/l). Serum aminotransferase activity was normal in all as was ultrasound examination of the liver and the spleen, performed in five of the six patients. Serology for EBV-VCA IgG and IgM, CMV IgM, adenovirus, and Toxoplasma gondii was negative in all. Anti- $B$ henselae IgM was present in all with an anti- $B$ henselae IgG titre of $1 / 1024$ or above. All children had a history of contact with kittens.

Antibiotic treatment with amoxicillin, ceftriaxone, or clarithromycin had been previously prescribed in five children; after diagnosis no specific treatment was administered and all patients recovered over two to eight weeks.

In the same period of time 62 children affected by EBV related infectious mononucleosis and 14 children with $B$ henselae infection but with different clinical presentations were observed in our paediatric department.

\section{Discussion}

The spectrum of recognised clinical manifestations of $B$ henselae infection in children has changed a great deal in recent years, with an increasing incidence of atypical presentations such as fever of unknown origin, hepatosplenic granulomatosis, pseudomalignant disorders, or acute encephalopathy. ${ }^{4}$

In Europe, cat scratch disease is considered rare, ${ }^{5}$ but our recent experience suggests that $B$ henselae infection may be frequent in north central Italy and is probably often undiagnosed. ${ }^{2}$

Even though some authors suggest that cat scratch disease should be included in the differential diagnosis of all lymphadenopathies, ${ }^{6}$ infectious mononucleosis like illness has not been specifically reported, even in a recent review, ${ }^{3}$ as a specific feature suggestive of $B$ henselae infection.

In our experience the clinical feature of infectious mononucleosis is a presentation of $B$ henselae infection. Clinical features are non-specific: patients are usually younger than 5 years, and present with persistent fever, pharyngitis, tonsillitis with or without exudate, nasal obstruction, periorbital oedema, painless bilateral cervical and submandibular lymphadenitis, and splenomegaly. However, surprisingly neutrophilia rather than lymphomonocytosis, normally typical of both infectious mononucleosis and infectious mononucleosis like illness, characterises the blood smear of these patients. For this reason we suggest the term "pseudoinfectious mononucleosis" to identify this type of onset of cat scratch disease. Other laboratory features supporting the diagnosis include increased ESR and C reactive protein, and hypergammaglobulinemia which may be notable.

The history of contact with a kitten may be a useful diagnostic feature and was present in all our patients.

Serology for $B$ henselae is a sensitive diagnostic procedure. ${ }^{3}$ High IgG $(\geqslant 1 / 1024)$ by serum immunofluorescence antibody test and detectable specific $\operatorname{Ig} M$ were present in all cases. False positive IgM serology for $B$ henselae has been reported during acute EBV infection ${ }^{7}$; however, all our patients had negative EBV IgG and IgM serology. In cases of suspected "pseudoinfectious mononucleosis", the significance of anti- $B$ henselae specific IgM should be reconfirmed by demonstration of negative EBV serology and by the presence of significant titres of anti-B henselae IgG.

The value of treatment of $B$ henselae infection in the immunocompetent host is debated; most of our patients had been previously treated with different oral antibiotics without evident success. However, as in most forms of $B$ henselae infection in children, "pseudoinfectious mononucleosis" in our patients was followed by complete recovery.

1 Lajo A, Borque C, Del Castillo F, Martin-Ancel A. Mononucleosis caused by Epstein virus and cytomegalovirus in children: a comparative study of 124 cases. Pediatr Infect Dis f 1994;13:56-9.

2 Massei F, Messina F, Talini I, Massimetti M, Palla G, Macchia P, Maggiore G. Widening the clinical spectrum of Bartonella henselae infection as recognised

3 Nadal D, Zbinden R. Serology to Bartonella (Rochalimaea) henselae, may replace traditional diagnostic criteria for cat scratch disease. Eur F Pediatr 1995;154:906-8.

4 Bass WJ, Vincent JN, Person DA. The expanding spectrum of Bartonella infections: II. Cat scratch disease. Pediatr Infect Dis $\mathcal{F}$ 1997;16:163 -79.

5 Karpathios T, Golphinos C, Psycou P, Garoufi A, Papadimitriou A, Nicolaidou P. Cat scratch disease, in Greece. Arch Dis Child 1998;78:64-6.

6 Boyer KM. Bartonella (cat scratch disease). In: Feigin RD, Cherry JD, eds. Textbook of pediatric infectious diseases. Philadelphia: WB Saunders, 1998:1512-17.

7 Zbinden R, Strohle A, Nadal D. IgM to Bartonella henselae in cat scratch disease during acute Epstein Barr virus infection. Med Microbiol Immunol 1998;186:167-70. 